\title{
War narratives in the book of Chronicles: A new proposal in respect of their function
}

\author{
P C Beentjes ${ }^{1}$ \\ Katholieke Theologische Universiteit Utrecht (The Netherlands) \\ Research Associate: University of Pretoria
}

\begin{abstract}
Research has shown that the majority of the narratives on war in the book of Chronicles have been created by the Chronicler himself. This article offers a fresh proposal that war narratives in the book of Chronicles are to be read and explained as a reflection of the factual military impotence of Yehud during the Persian period. This military weakness has been transformed into a theological concept in which it is God who wages war in favour of the people seeking God. The outcome of these divine actions depends on the people of Judah's attitude, whether they "seek the Lord" or "abandon the Lord". Therefore, these war narratives should not be traced back to the concept of holy war.
\end{abstract}

\section{INTRODUCTION}

At first sight, the book of Chronicles appears to be a rather unattractive document. This is especially true in respect of its setting within the Christian Bible, where the book of Chronicles is preceded by 1 and 2 Samuel and 1 and 2 Kings. Having read these latter writings, the book of Chronicles seems to be nothing more than a mere repetition of them. However, if one takes time to plunge into the book of Chronicles, which was written between 400 and $300 \mathrm{BCE}$

\footnotetext{
${ }^{1}$ Prof Dr P C Beentjes (Katholieke Theologische Universiteit Utrecht, the Netherlands) is a research associate of Prof Dr A P B Breytenbach, Department of Old Testament Studies, University of Pretoria. Prof Breytenbach visited Prof Beentjes in Utrecht in 2002. This article was presented at the conference "Religion and Violence", organized by The Netherlands School for Advanced Studies in Theology and Religion (NOSTER), Soesterberg, the Netherlands, 20-22 January 2003.
} 
during the Persian period (Grabbe 1994:27-145), it has a tremendous appeal to its reader, even in such a way that one becomes fond of it and decides to write a commentary on this religious document (Beentjes: 2002).

In past decades, a number of studies on the book of Chronicles have been published in which "war" is explicitly dealt with. Peter Welten devoted a chapter on "war reports" (Kriegsberichte) in his revised Habilitationsschrift of 1971(Welten 1973:115-175). Since his analysis confined itself to 2 Chronicles 10-36, quite a number of passages about war are not discussed at all. ${ }^{2}$ Ingeborg Gabriel, who in her 1990 Vienna dissertation analyses the concept of "peace" in the book of Chronicles, naturally touches on the theme of war (Gabriel 1990). However, since in 1 Chronicles 1-9 the notion "peace" does not occur, these chapters have not been treated by her at all and as a consequence the notion "war" is therefore kept out of sight here. In respect of her study, at least one further comment should be made: At the end of her doctoral thesis, Gabriel states the following about war narratives in the first book of Chronicles: "Die Kriege in I Chr übernimmt die Chr fast unverändert aus der Vorlage in 2 Sm" (Gabriel 1990:192 n 55), which is not true, as can be seen in Table 1, category C, below. In 1992 Andreas Ruffing published a revised edition of his doctoral thesis on wars waged by God in the book of Chronicles. In this monograph he restricted himself, however, to three major narratives on war that all belong to the Chronicler's own material or Sondergut. ${ }^{3}$ Recently John Wright has published an article in which, at last, the whole book of Chronicles is in the centre of attention (Wright 1997:150-177). However, since his contribution has focused upon the topic of the Chronicler as historian, I would like to pay attention to another aspect of war in the book of Chronicles, which to the best of my knowledge has not been dealt with earlier in this way.

\footnotetext{
${ }^{2}$ Welten offers an analysis of five pericopes: 2 Chron 13:3-20; $14: 8-14 ; 20: 1-30 ; 26: 3-8$, and 27:56

${ }^{3}$ His analysis relates to $2 \mathrm{Chr} 13: 2 \mathrm{c}-18 ; 14: 7-14 ; 20: 1-30$
} 


\section{WAR IN CHRONICLES}

Since there are a lot of conflicts in the book of Chronicles, the author uses a wide range of terminology to describe such situations, for example "to strike" (ףג qal),

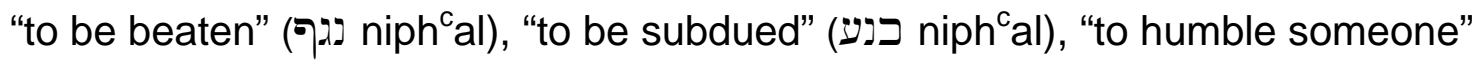

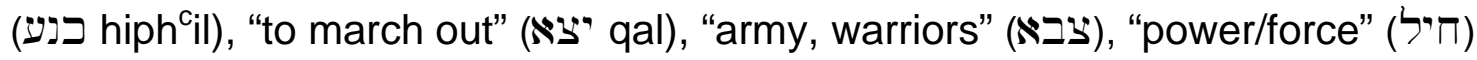
(see especially Weinberg 1985: 114-122). The present contribution, however, will confine itself strictly to the topic of "war" (מלחמה) (cf Preuss 1997: 334-345). As far as statistics are concerned, it should be noticed that the noun מלחמה ("war") is used quite often in the book of Chronicles. Out of a total number of 318 occurrences in the Hebrew Bible, מלחמה is found no less than 63 times in 1-2 Chronicles, that is $19,8 \%$ of the total. Since the text of the book of Chronicles, however, covers only 8-8,5\% of the Hebrew Bible (Jenni \& Westermann 1979: 540 ), the real percentage of 19,8 is so high that it asks for an explanation. In order to be able to provide such, we have to review the evidence.

In Table 1 the occurrences of the noun מלחמה have been grouped under three headings. The first group (A) consists of מלחמה-passages, which have just been copied by the Chronicler from their parent texts in 1-2 Samuel and 1-2 Kings. The second category (B) refers to those passages which on the one hand have been adopted by the Chronicler from their parent texts in 1-2 Samuel and 12 Kings, but on the other hand have been changed and/or extended by him. The third group (C), which is the most extensive by far, shows all those passages that are the Chronicler's own material (Sondergut). It is within this latter category in particular that we have to look for an answer to the question why the author of the book of Chronicles uses the concept of war so often. In Table 2 the same procedure has been pursued relating to the verb לחם (niph ${ }^{\mathrm{C} a l)}$, which is used 164 times in the Hebrew Bible, of which 18 occurrences (namely 11\%) are found in 12 Chronicles (11\%). 
Table 1 - The occurrence of the noun מלחמה ("war/fight") in the book of Chronicles according to different categories.

\begin{tabular}{|c|c|c|}
\hline Category A (16 x) 25,4\% & Category B (8x) $12,7 \%$ & Category C (39 x) 61,9\% \\
\hline & & 15:10 \\
\hline & & $5: 18,19,20,22$ \\
\hline & & $17: 4,11,40$ \\
\hline \multirow{2}{*}{\multicolumn{3}{|c|}{$\frac{\mid 10: 3}{111: 13}$}} \\
\hline & \\
\hline & & \begin{tabular}{|l}
$12: 1,9,20,34,36,37,38,39$ \\
$14: 15$
\end{tabular} \\
\hline |19:9, 10, 14 & 19:7, 17 & \\
\hline \multirow[t]{4}{*}{$120: 6$} & $20: 4$ & $120: 5$ \\
\hline & & $122: 8$ \\
\hline & & I26:27 \\
\hline & & 128:3 \\
\hline \multirow{2}{*}{\multicolumn{3}{|c|}{$\begin{array}{l}116: 34 \\
168: 9 \\
\mid 111 \cdot 1\end{array}$}} \\
\hline & & \\
\hline \multicolumn{3}{|c|}{ II 12:15 } \\
\hline & II 13:2 & II $13: 3^{3}, 14$ \\
\hline & & II 14:5, 9 \\
\hline & & $\frac{11}{\| 169: 9}$ \\
\hline \multirow[t]{2}{*}{ II $18: 5,14,29^{2}, 34$} & II $18: 3$ & \\
\hline & & II $20: 1,15$ \\
\hline \multirow[t]{5}{*}{$1122: 5$} & & \\
\hline & & II 25:8, 13 \\
\hline & II 27:7 & \\
\hline & & II $32: 2,6,8$ \\
\hline & & II 35:21 \\
\hline
\end{tabular}

Table 2 - The occurrence of the verb לחם (niph ${ }^{\mathrm{c} a l),}$,to battle with/fight", in the book of Chronicles according to different categories.

\begin{tabular}{|c|c|c|}
\hline Category A (7 x) 38,9\% & Category B (2x) $11,1 \%$ & Category C (9 x) 50\% \\
\hline & $110: 1$ & \\
\hline \multirow{2}{*}{\multicolumn{3}{|c|}{ 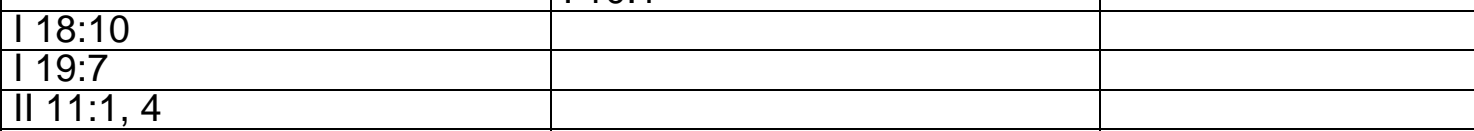 }} \\
\hline & & \\
\hline & & II 13:12 \\
\hline & & II 17:10 \\
\hline \multicolumn{3}{|l|}{ II 18:30, 31} \\
\hline \multirow{7}{*}{$1122: 6$} & & II 20:17, 29 \\
\hline & & \\
\hline & & II 26:6 \\
\hline & & II 27:5 \\
\hline & & II 32:8 \\
\hline & $1135: 20(? ?)$ & \\
\hline & & $1135: 22^{2}$ \\
\hline
\end{tabular}




\section{DAVID, SOLOMON AND WAR}

Looking at these charts, it is striking that the concept of war is completely absent from the book of Chronicles during the reign of king Solomon (2 Chr 1-9). We here encounter a presentation that has been created deliberately by the Chronicler. This is shown by two passages that occur earlier in the book, namely $1 \mathrm{Chr} 22: 3$ and 28:3. These two texts are solid proof that the author of Chronicles wrestled with a huge problem: Why was David, his favourite king, not allowed to build the Jerusalem temple? First, of course, there was an indisputable tradition that it had been Solomon who erected the house of God in Jerusalem. Already in early tradition, a historical explanation had been offered for this. According to 1 Kings 5:17 Solomon said: "You know that my father David could not built a house for the name of the Lord his God, because of the armed nations surrounding him ..." (translation according to the Revised English Bible). The Chronicler, however, has radically changed this traditional explanation, putting forward a theological argument. In his presentation, it is God who explicitly forbade David to build the temple, "since he waged great wars" (1 Chr 22:8). Here we come across the reason why the Chronicler in $1 \mathrm{Chr}$ 17:1 has skipped a full line from 2 Samuel 7:1 ("Once ... the Lord had given him [David] rest from his enemies on all sides, ..."): To the Chronicler the notion of "rest" is explicitly connected to Solomon, who in 1 Chr 22:9 is therefore described as "man of rest" (איש מנוחה). The theological argument about God's prohibition at David's address is first brought to the fore in a private meeting between David and Solomon (1 Chr 22:6-13) and is repeated later during a public audience (1 Chr 28:2-10) in which the Chronicler has David state that he is "a man of wars" (איש מלחמות). Here we have a solid piece of evidence that the concept of war might have a special function in the book of Chronicles.

\section{WAR THEOLOGISED}

The first passage on war in the book of Chronicles is found in 1 Chr 5:18-22. This text is encountered in what most people consider one of the most boring parts of 
the entire Hebrew Bible: the genealogies of 1 Chr 1-9. ${ }^{4}$ A close reading of these nine chapters, however, brings to light that they in fact contain the blueprint of all the Chronicler's concepts and conceptions. With regard to $1 \mathrm{Chr} 5: 18-22$, it can hardly be a coincidence that this passage, which belongs to the Chronicler's own material, is explicitly concerned with theological aspects of war. The particular feature of this pericope, dealing with the tribes of Transjordan, is not so much that they convey information about their adversaries (Hagarites, Jetur, Nephish, and Nodab) as it is to make the point that "the war was of God's making" (5:22). ${ }^{5}$ That this war was indeed God's concern is indicated twice with the help of a passivum divinum: "they were given help" and "they were given in their hand" $(5: 20)$. The subsequent causal sentence is of eminent importance, for here we find the key to the Chronicler's theological point of view: "for they cried to their God for help in the war, and He was supplicated [עתר] by them, because they trusted him [בטח]". It is quite remarkable that the verb "to trust" (בטח) will be used only one more time, namely within the very explosive context of $2 \mathrm{Chr} 32: 10$, when Jerusalem is under Assyrian siege. Elsewhere in his book the Chronicler will continually use his favourite set phrase "to seek guidance of the Lord" (דרש את יהוה) (Begg 1982:128-141).

It is not only the remarkable theological content of $1 \mathrm{Chr} 5: 18-22$ that strikes the eye. It is also the placing of $1 \mathrm{Chr} 5: 18-23$ that points to its particular function. After the pericope dealing with the tribe of Gad (5:11-17), one would rather expect another topic, namely the presentation of the half-tribe of Manasseh, but that is now to be found in 5:23-24. The report about their common war, which is now presented in between (5:18-23), should have been the conclusion. Suppose the Chronicler had chosen that sequence indeed, he would have caused a huge theological problem, since in that case God's explicit help in this war (5:20-22) would have been immediately followed by the abduction into the Babylonian exile which has also been effected by him (5:25-26; Japhet

4 The most extensive study dealing with 1 Chronicles 1-9 is that of Oeming (1990).

${ }^{5}$ Hagarites are also mentioned in 1 Chron 5:10; Jetur and Nephish are also mentioned in Gen 25:15 and; 1 Chron 1:31); Nodab is mentioned only here in the Hebrew Bible 
1999:33-43). The Chronicler managed to prevent this problem by moving the passage relating to the half-tribe of Manasseh backwards. In doing so, the logical structure of the chapter ( $\mathrm{Gad}$, half-Manasseh, their common war) is subordinated to the theological concept of the Chronicler, which requires another sequence (Gad, their common war, half-Manasseh).

\section{WAR AS GOD'S CONCERN}

In the book of Chronicles waging a war is always God's concern. The opinion that warfare by human beings could bring salvation to the people of Israel is refuted over and over again. Only God himself is able to save, and only under the strict condition that people evince their faithful attitude towards Him. It is no coincidence, therefore, that the formula "to seek guidance of the Lord", 6 together with its counterpart "to abandon the Lord", 7 is found with particular frequency in the narratives related to the divided monarchy (2 Chr 10-36). That we have to do with theological narratives rather than with historical reports is, for example, shown by a kind of mathematical feature. In those cases where Judah gains the victory over their opponent(s), the size of the Judean army is half as large as that of their enemies. In 2 Chr 13:3, Abijah's troops number 400 000, whereas Jeroboam came up against him with 800000 picked troops. With God's help 500000 men of Israel fell in the battle (2 Chr 13:7). The same pattern is found in $2 \mathrm{Chr}$ 14:8-9: King Asa has 580000 men, whereas Zerah the Cushite marched out against him with an army a million strong. The Lord, however, gave Asa and Judah victory over the Cushites (2 Chr 14:12). ${ }^{8}$ That we indeed have to do with a theological pattern, is proven by a battle-report with an opposite outcome: "At the turn of the year a force of Aramaeans advanced against Joash; they invaded Judah and Jerusalem .... Although the Aramaeans had invaded with a small force, the Lord

${ }^{6} 2$ Chr 14:3, 6, 7; 15:2, 4, 12, 13, 15; 16:12; 17:4; 18:4, 7; 19:3; 20:3; 22:9; 26:5²; 30:19; 31:21 $34: 3,21,26$.

72 Chr 12:1, 5; 13:10, 11; 15:2; 21:10; 24:18, 20, 24; 28:6; 29:6; 34:25.

8 I do not understand why G Knoppers (1999:200 n 59) in this connection refers to 2 Chr 32:8. We will discuss this verse later on, however, for quite another reason. 
delivered a very great army in their power, because the people [of Judah] had forsaken the Lord the God of their forefathers ..." (2 Chr 24:23-24).

Time and again, the author of the book of Chronicles brings out that war is God's concern. In a very fine way this is emphasized in $2 \mathrm{Chr} 20: 15$, which is part of a prophetic address by Jahaziel (2 Chr. 20:14-17). Verse 15b functions as the motivation in the prophet's summon not to be dismayed; Israel will be out of harm's way: "For it is not your war, but the Lord's one". Whether the phrase in 2 Chr 20:15b (לא לכם המלחמה כי לאלהים) is indeed such a plain parallel to 1 Samuel 17:47 (כי ליהוה המלחמה), as is the conviction of so many authors, must be seriously doubted. For the wording of it is set in a negative structure, which is very rare. It is found nowhere else in the entire Old Testament. Elsewhere I have adduced arguments that $2 \mathrm{Chr} 20: 14-17$ is much better considered as a perfect parallel of Ex 14:13-14 (Beentjes 1993: 263-268).

$2 \mathrm{Chr} 32: 8$ is also a good example to show that war in the book of Chronicles is exclusively seen as an action of God. In $2 \mathrm{Chr} 32: 2-9$, which no doubt is his own Sondergut, the Chronicler makes Hezekiah, one of his most favoured kings, address the people of Jerusalem in the following way: "Be strong; be brave. Do not let the king of Assyria or the rabble he has brought with him strike terror or panic into your hearts, for we have more on our side than he has. He has human strength; but we have the Lord our God to help us and to fight our battles" (2 Chr 32:7-8). This again is a solid piece of evidence that the Chronicler has created a consistent theological paradigm relating to war.

\section{WHY ATTRIBUTE WAR TO GOD?}

Could we provide an answer to the question why the Chronicler is so tenacious in attributing war to God? The answer to this question must be sought in the following direction: After the Babylonian exile, the former kingdom of Judah had been reduced to Yehud, an insignificant province of the Persian Empire. There was no Davidic dynasty, no king ruling the country, nor any Judean army. The only power left to rely on was Yhwh, and the only institution left was the house of God that had been rebuilt with permission of the Persian authorities. As a matter 
of fact, temple and cult became the centre of the post-exilic Judean community (Weinberg 1992). No wonder that warfare in the Book of Chronicles is sometimes described more as a liturgical event than a clash of warriors (2 Chr 13:12-15; 20:5-21), for the only power to protect the Judean people was their God. I fully agree with John Wright that the battle accounts have a programmatic function within the Chronicler's own situation and reveal much more about the Chronicler's aspirations than about the historical events they are supposed to refer to (Wright 1997: 176). Knoppers is also correct when he states: "The Chronicler, like other ancient Near Eastern historians, constructs history not merely out of an antiquarian interest, but to affect the present" (Knoppers 1993: 530).

\section{CONCLUSION}

Though they are presented as historical battle reports, many narratives on war in the book of Chronicles should in fact be considered as concealed claims that God will protect his people, since Yehud did not have a force of their own to do this. It is no coincidence therefore that in so many Chronistic war reports God's presence and power is articulated to such a high degree (1 Chr 14:11, 15; $2 \mathrm{Chr}$ $14: 10 ; 20: 6,15,17 ; 32: 8,11,14,18)$. The war narratives in the book of Chronicles can therefore be considered as a reflection of the factual military impotence of Yehud during the Persian Period. The Chronicler has transformed this impotence into a theological concept of God's violent interventions. The outcome of these divine actions depends on the people of Judah's attitude, whether they "seek the Lord" or "abandon the Lord".

It is unlikely that the war narratives in the book of Chronicles should be traced back to the concept of holy war. For, as Weinberg has demonstrated, the large majority of the Chronicler's war narratives miss essential and/or constitutive holy war elements, which are indissolubly connected to the classical scheme of holy war as brought to the fore by G von Rad (Weinberg 1985:123-4, especially Tabelle 2). 


\section{Works consulted}

Beentjes, P C 1993. Tradition and transformation: Aspects of innerbiblical interpretation in 2 Chronicles 20. Biblica 74, 258-268.

Beentjes, P C 2002. 1 Kronieken. Kampen: Kok. (Verklaring van de Hebreeuwse Bijbel.)

Begg, C 1982. "Seeking Yahweh" and the purpose of Chronicles. (Louvain Studies 91.)

Grabbe, L L 1994. Judaism from Cyrus to Hadrian. London: SCM.

Gabriel, I 1990. Friede über Israel: Eine Untersuchung zur Friedenstheologie in Chronik I 10-II 36. Klosterneuburg: Österreichisches Katholisches Bibelwerk. (Österreiche Biblische Studien 10.)

Jenni, E \& Westermann, C (eds) 1997. Theologisches Handwörterbuch zum Alten Testament, Band II. München: Chr. Kaiser.

Japhet, S 1999. Exile and restoration in the book of Chronicles, in Becking, B \& Korpel, M C A (eds), The crisis of Israelite religion: Transformation of religious traditions in exilic and post-exilic times. Leiden: Brill. (OTS 42.)

Knoppers, G 1993. "Battle against Yahweh": Israel's war against Judah in 2 Chr 13:2-20. $R B$ 100, 511-532.

Knoppers, G 1999. Treasures won and lost: Royal (mis)appropriations in Kings and Chronicles, in Graham, M P \& McKenzie, S L (eds), The Chronicler as author: Studies in text and texture Sheffield: Sheffield Academic Press. (JSOTS 263.)

Oeming, M 1990. Das wahre Israel: Die »genealogische Vorhalle« 1 Chronik 1-9. Stuttgart: Kohlhammer. (BWANT 128.)

Preuss, H D 1997. s v מלחמה milchama. TDOT VIII. Grand Rapids: Eerdmans.

Ruffing, A 1992. Jahwekrieg als Weltmetapher: Studien zu Jahwekriegstexten des chronistischen Sondergutes. Stuttgart: Katholisches Bibelwerk GmbH. (SBB 24.)

Weinberg, J P 1985. Krieg und Frieden im Weltbild des Chronisten. Orientalia Lovaniensia Periodica 16, 111-129.

Weinberg, J P 1992. The citizen-temple community. Sheffield: Sheffield Academic Press. (JSOTS 151.)

Welten, P 1973. Geschichte und Geschichtsdarstellung in den Chronikbüchern. Neukirchen-Vluyn: Neukirchener Verlag. (WMANT 42.)

Wright, J W 1997. The fight for peace: Narrative and history in the battle accounts in Chronicles, in Graham, M P, Hoglund K G \& McKenzie, S L (eds), The Chronicler as Historian. Sheffield: Sheffield Academic Press. (JSOTSS 238.) 